Marquette University

e-Publications@Marquette

Biological Sciences Faculty Research and

Publications

Biological Sciences, Department of

$5-26-2009$

\title{
Insight into the Carboxyl Transferase Domain Mechanism of \\ Pyruvate Carboxylase from Rhizobium etli
}

\author{
Tonya N. Zeczycki \\ University of Wisconsin - Madison \\ Martin St. Maurice \\ Marquette University, martin.stmaurice@marquette.edu \\ Sarawut Jitrapakdee \\ Mahidol University \\ John C. Wallace \\ University of Adelaide \\ Paul V. Attwood \\ University of Western Australia
}

See next page for additional authors

Follow this and additional works at: https://epublications.marquette.edu/bio_fac

Part of the Biology Commons

\section{Recommended Citation}

Zeczycki, Tonya N.; Maurice, Martin St.; Jitrapakdee, Sarawut; Wallace, John C.; Attwood, Paul V.; and Cleland, W Wallace, "Insight into the Carboxyl Transferase Domain Mechanism of Pyruvate Carboxylase from Rhizobium etli" (2009). Biological Sciences Faculty Research and Publications. 290.

https://epublications.marquette.edu/bio_fac/290 


\section{Authors}

Tonya N. Zeczycki, Martin St. Maurice, Sarawut Jitrapakdee, John C. Wallace, Paul V. Attwood, and W Wallace Cleland 


\section{Insight into the Carboxyl Transferase Domain Mechanism of Pyruvate Carboxylase from Rhizobium etli}

\section{Tonya N. Zeczycki}

Institute for Enzyme Research and Department of Biochemistry,

University of Wisconsin,

Madison, WI

Martin St. Maurice

Department of Biological Sciences, Marquette University,

Milwaukee, WI

Sarawut Jitrapakdee

Department of Biochemistry, Faculty of Science,

Mahidol University,

Bangkok, Thailand

John C. Wallace

School of Molecular and Biomedical Science,

University of Adelaide,

Adelaide, SA 5005, Australia

Paul V. Attwood

School of Biomedical, Biomolecular and Chemical Sciences,

University of Western Australia,

Crawley, WA, Australia 


\title{
W. Wallace Cleland \\ Institute for Enzyme Research and Department of Biochemistry, University of Wisconsin, Madison, WI
}

\begin{abstract}
The effects of mutations in the active site of the carboxyl transferase domain of $R$. etli pyruvate carboxylase have been determined for the forward reaction to form oxaloacetate, the reverse reaction to form MgATP, the oxamate-induced decarboxylation of oxaloacetate, the phosphorylation of MgADP by carbamoyl phosphate and the bicarbonatedependent ATPase reaction. Additional studies with these mutants examined the effect of pyruvate and oxamate on the reactions of the biotin carboxylase domain. From these mutagenic studies, putative roles for catalytically relevant active site residues were assigned and a more accurate description of the mechanism of the carboxyl transferase domain is presented. The T882A mutant showed no catalytic activity for reactions involving the carboxyl transferase domain, but surprisingly showed a 7- and 3.5-fold increase in activity, as compared to the wild-type enzyme, for the ADP phosphorylation and bicarbonate-dependent ATPase reactions, respectively. Furthermore, the partial inhibition of the T882A catalyzed BC domain reactions by oxamate and pyruvate further supports the critical role of Thr882 in the proton transfer between biotin and pyruvate in the carboxyl transferase domain. The catalytic mechanism appears to involve the decarboxylation of carboxybiotin and proton removal from Thr882 by the resulting biotin enolate with either a concerted or subsequent transfer of a proton from pyruvate to Thr882. The resulting enolpyruvate then reacts with $\mathrm{CO}_{2}$ to form oxaloacetate and complete the reaction.
\end{abstract}

Pyruvate carboxylase ( $\mathrm{PC}^{1}$, EC 6.4.1.1), a multifunctional biotindependent enzyme, is physiologically important in the metabolic pathway for glucose production and has an anaplerotic role in replenishing oxaloacetate in the TCA cycle. ${ }^{1}$ Pyruvate carboxylation is a multi-step reaction that occurs at two spatially distinct active sites (Scheme 1 ). ${ }^{2}$ In the first partial reaction, a bicarbonate-dependent ATP cleavage is coupled to the carboxylation of the covalently attached biotin prosthetic group in the biotin carboxylase $(B C)$ domain through the formation of a putative carboxyphosphate intermediate. ${ }^{3}$ Carboxybiotin then moves to the carboxyl transferase (CT) domain where the carboxyl group is transferred from biotin to pyruvate, forming oxaloacetate, and a proton is transferred from pyruvate to 
biotin. The recent crystal structure of the PC holoenzyme from Rhizobium etli (RePC) and mutagenic studies demonstrated that the movement of carboxybiotin occurs between the BC and CT domains from opposing polypeptide chains and is partially mediated by conformational changes in the enzymic tetramer induced by the binding of the allosteric effector, acetyl-CoA. ${ }^{4}$

$$
\mathrm{MgATP}+\mathrm{HCO}_{3}^{-}+\mathrm{E} \text {-biotinH } \stackrel{\mathrm{Mg}^{2+}, \text { acetyl CoA }}{=} \mathrm{E}^{-} \text {biotin } \mathrm{CO}_{2}^{-}+\mathrm{MgADP}+\mathrm{P}_{\mathrm{i}}
$$

Scheme 1. Partial reactions of the biotin carboxylase (1) and carboxyl transferase (2) domains for the overall reaction catalyzed by pyruvate carboxylase.

Several different mechanisms have been proposed for the carboxyl transfer. ${ }^{5}$ Kinetic isotope effect studies ${ }^{6,7}$ and $\mathrm{pH}$ profiles ${ }^{8}$ of the forward and reverse reactions occurring in the CT domain are most consistent with a stepwise mechanism where biotin decarboxylation, proton transfer, and pyruvate carboxylation occur through the formation of distinct biotin enolate and enolpyruvate intermediates. ${ }^{9}$ Concentrated efforts have been made to identify catalytic residues responsible for facilitating the carboxyl transfer based on sequence conservation among PCs from various sources and the homologous 5S subunit of transcarboxylase ${ }^{10}$ in an attempt to detail individual reaction steps in the mechanism. Unfortunately, the lack of high-resolution crystal structures of the PC holoenzyme has led to a great deal of speculation as to the location and catalytic function of residues previously targeted for mutagenic studies. ${ }^{11}$ The determination of crystal structures of PC from human (hPC) and Staphylococcus aureus (SaPC) revealed the relative positioning of ligands and residues in the CT domain active site. ${ }^{12}$ This new structural insight, coupled with the structure of the RePC holoenzyme, allowed for a more focused mutagenic study in an attempt to fully elucidate a detailed carboxyl and proton transfer mechanism in the CT domain. The current work entails an extensive examination of the catalytic roles of several previously unexplored residues of the CT domain. The wild-type and mutant forms of RePC were characterized with respect to their catalytic activities for the full and partial reactions of the BC and CT

Biochemistry, Vol 48, No. 20 (May 26, 2009): pg. 4305-4313. DOI. This article is (c) American Chemical Society and permission has been granted for this version to appear in e-Publications@Marquette. American Chemical Society does not grant permission for this article to be further copied/distributed or hosted elsewhere without the express permission from American Chemical Society. 
domains. Based on the present data, we propose a reaction mechanism for carboxyl transfer in the CT domain involving a crucial threonine residue. In addition, we demonstrate that mutations in the $\mathrm{CT}$ domain have a pronounced effect on reaction rates in the $\mathrm{BC}$ domain and we offer evidence to suggest the intrinsic communication between the reactions of the two individual domains of PC is specifically mediated through the tethered biotin cofactor.

\section{Materials and Methods}

\section{Materials}

IPTG, ampicillin and Chloramphenicol were from RPI. All other compounds were from Sigma/Aldrich and were obtained at the highest available purity.

\section{Methods}

Overexpression and Purification of Protein E. coli HMS174(DE3) was transformed with the pET-17b (His) ${ }_{9}$ RePC plasmid $^{4}$ for expression of wild-type PC. Mutants were generated by the Quickchange sitedirected mutagenesis protocol (Stratagene, La Jolla, CA) using primers designed to incorporate the selected mutations, Table S1. Mutagenesis was performed using a $1.2 \mathrm{~kb}$ BamHI-NotI fragment of $R$. etli PC gene ${ }^{13}$ cloned in pBluescript (Stratagene) as a template. Mutagenic reactions were performed as previously described. ${ }^{14}$ The nucleotide sequences of all mutants were verified by automated sequencing. The BamHI-NotI mutagenic cassettes were then replaced the BamHI-NotI wild-type fragment of the expression clone. ${ }^{4}$

Wild-type and mutant forms of $R$. etli $\mathrm{PC}$ were expressed in $40 \mathrm{~L}$ batch cultures of LB media (containing $200 \mu \mathrm{g} / \mathrm{mL}$ ampicillin, $30 \mu \mathrm{g} / \mathrm{mL}$ Chloramphenicol and $1 \mathrm{mg} / \mathrm{L}$ biotin) which were inoculated with an $1 \mathrm{~L}$ overnight culture of $E$. coli HMS174(DE3) transformed with either the wild-type or mutant forms of the pET-17b (His) ${ }_{9}$ RePC plasmid and the pCY216 plasmid containing biotin protein ligase (BirA). ${ }^{15}$ Large scale fermentations were carried out in a $50 \mathrm{~L}$ carboy equipped with an air inlet hose which was connected to the house air line and fitted with a gas diffusion stone to ensure proper aeration and agitation of the

Biochemistry, Vol 48, No. 20 (May 26, 2009): pg. 4305-4313. DOI. This article is (c) American Chemical Society and permission has been granted for this version to appear in e-Publications@Marquette. American Chemical Society does not grant permission for this article to be further copied/distributed or hosted elsewhere without the express permission from American Chemical Society. 
media throughout growth and induction. Batch cultures were grown at $37^{\circ} \mathrm{C}$ to an $\mathrm{OD}_{600}=0.9-1.2$. Arabinose (final concentration $20.8 \mathrm{mM}$ ) and IPTG (final concentration $1 \mathrm{mM}$ ) were added to the carboy, which was then chilled on ice for 20 min prior to transferring to a $16^{\circ} \mathrm{C}$ water bath for approximately 20-24 h. Cells were harvested, yielding 100$200 \mathrm{~g}$ of cell paste. Wild-type and mutant RePC were purified using $\mathrm{Ni}^{2+}$-affinity chromatography. ${ }^{4}$ The purified recombinant protein, containing the (His), $\mathrm{N}$-terminal tag, was concentrated to $\sim 10 \mathrm{mg} / \mathrm{mL}$ for kinetic studies, flash frozen in $500 \mu \mathrm{L}$ aliquots, and stored at $-80^{\circ}$ C. The enzyme concentration was determined spectrophotometrically using the calculated molar extinction coefficient of $118000 \mathrm{M}^{-1} \mathrm{~cm}^{-1}$ at $280 \mathrm{~nm}$. Typical yields were $\sim 5.5 \mathrm{mg} / \mathrm{L}$. Biotinylation levels of the protein were determined using SDS-PAGE analysis after incubation with avidin and were estimated to be greater than $98 \%$ for all enzyme forms, with the exception of the K1119Q mutant which showed no incorporation of biotin.

\section{Enzyme Assays}

All enzyme assays used in this study were performed using coupled assay systems which are shown in Table 1.

Table 1. Enzymatic reactions and assays used for determination of the effects of CT domain mutations in pyruvate carboxylase from $R$. etli a

\section{Reactions $^{\text {b }}$}

Pyruvate Carboxylation: Forward reaction (BC and $\mathrm{CT})^{\mathrm{c}}$

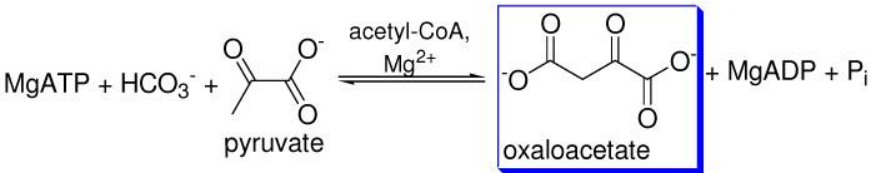

Oxaloacetate decarboxylation: Reverse reaction (CT and BC domains)

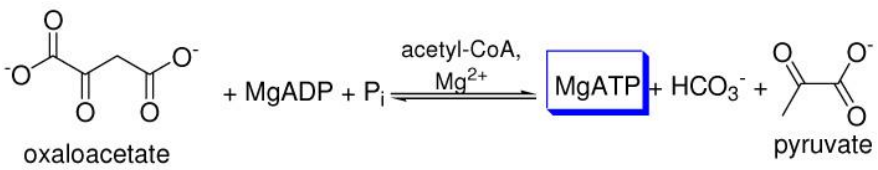

Oxamate-induced oxaloacetate decarboxylation: Reverse reaction (CT)<smiles>O=C(O)CC(=O)C(=O)[O-]</smiles>
oxaloacetate
Assay

malate dehydrogenase

hexokinase/glucose$6-$ phosphate dehydrogenase

lactate dehydrogenase

Biochemistry, Vol 48, No. 20 (May 26, 2009): pg. 4305-4313. DOI. This article is (c) American Chemical Society and permission has been granted for this version to appear in e-Publications@Marquette. American Chemical Society does not grant permission for this article to be further copied/distributed or hosted elsewhere without the express permission from American Chemical Society. 
NOT THE PUBLISHED VERSION; this is the author's final, peer-reviewed manuscript. The published version may be accessed by following the link in the citation at the bottom of the page.

Reactions $^{b}$

Assay

Bicarbonate-dependent ATPase: Forward reaction (BC) acetyl-CoA,

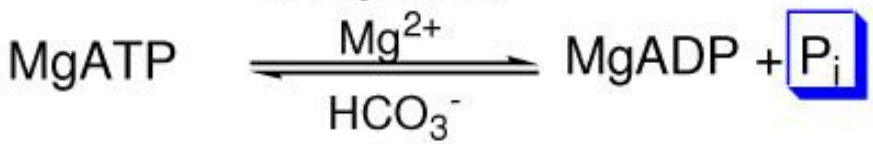

glucose-6-phosphate dehydrogenase/ phosphoglucomutase/ phosphorylase $a$

ADP phosphorylation: Reverse reaction (BC)

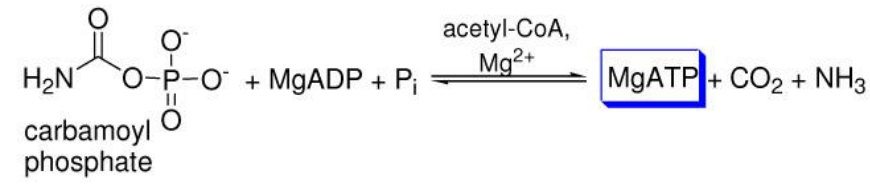

hexokinase/glucose-

6-

phosphate dehydrogenase

aproducts highlighted are those assayed to determine specific activities and initial rates.

bDetailed reaction and assay conditions in are described in the Methods section.

'Domains involved in the reaction, $\mathrm{BC}=$ biotin carboxylase, $\mathrm{CT}=$ carboxyl transferase.

\section{Pyruvate Carboxylation Activity}

Pyruvate carboxylation activity was determined by measuring the conversion of oxaloacetate to malate using malate dehydrogenase. ${ }^{8}$ All assays were performed at $25^{\circ} \mathrm{C}$ in a total reaction volume of $1 \mathrm{~mL}$ and were initiated with the addition of PC ( 5-500 $\mu \mathrm{g})$. Specific activities were determined, in triplicate, at saturating conditions of all substrates. Reported errors are standard deviations. The $(\mathrm{V} / \mathrm{K})_{\text {pyruvate }}$ was determined by varying pyruvate $(0.3-4.0 \mathrm{mM})$ at fixed bicarbonate, ATP, and acetyl-CoA concentrations. Assay conditions, except when pyruvate was the varied substrate, were 100 mM Tricine ( $\mathrm{pH} 7.5), 10 \mathrm{mM}$ pyruvate, $10 \mathrm{mM} \mathrm{HCO}_{3}{ }^{-}, 2.5 \mathrm{mM} \mathrm{MgATP}$, $2.5 \mathrm{mM} \mathrm{MgCl}_{2}, 0.25 \mathrm{mM}$ acetyl-CoA, $0.25 \mathrm{mM} \mathrm{NADH}$ and malate dehydrogenase (10 U).

\section{Activities of the Full Reverse Reaction}

The decarboxylation activity of oxaloacetate in the absence of oxamate was determined by monitoring the production of ATP using the hexokinase/glucose-6-phosphate dehydrogenase coupled assay system. All assays were performed at $25^{\circ} \mathrm{C}$ in a reaction volume of 3 $\mathrm{mL}$. Specific activities were determined in triplicate and reactions were initiated with the addition of PC (200-980 $\mu \mathrm{g})$. Specific activities were determined from reactions containing $100 \mathrm{mM}$ Tricine $(\mathrm{pH} 7.5), 3.0$ $\mathrm{mM} \mathrm{MgCl}$, $3.0 \mathrm{mM}$ MgADP, $2.0 \mathrm{mM}$ phosphate, $0.5 \mathrm{mM}$ oxaloacetate,

Biochemistry, Vol 48, No. 20 (May 26, 2009): pg. 4305-4313. DOI. This article is (C) American Chemical Society and permission has been granted for this version to appear in e-Publications@Marquette. American Chemical Society does not grant permission for this article to be further copied/distributed or hosted elsewhere without the express permission from American Chemical Society. 
NOT THE PUBLISHED VERSION; this is the author's final, peer-reviewed manuscript. The published version may be accessed by following the link in the citation at the bottom of the page.

$0.25 \mathrm{mM}$ acetyl-CoA, $0.20 \mathrm{mM}$ D-glucose, $0.23 \mathrm{mM}$ NADP, glucose-6phosphate-dehydrogenase $(5 \mathrm{U})$ and hexokinase $(1 \mathrm{U})$

\section{Oxamate-induced Decarboxylation of Oxaloacetate}

The decarboxylation activity in the presence of oxamate was determined by measuring the reduction of pyruvate to lactate using lactate dehydrogenase. ${ }^{8}$ All assays were performed at $25^{\circ} \mathrm{C}$ in a total volume of $3 \mathrm{~mL}$. Specific activities were determined in triplicate at saturating concentrations of all substrates, and reactions were initiated with the addition of PC (300-900 $\mu \mathrm{g})$. Reactions contained $100 \mathrm{mM}$ Tricine ( $\mathrm{pH} 7.5$ ), $3 \mathrm{mM} \mathrm{MgCl}_{2}, 0.5 \mathrm{mM}$ oxaloacetate, $0.5 \mathrm{mM}$ oxamate, $0.25 \mathrm{mM}$ acetyl-CoA, $0.24 \mathrm{mM} \mathrm{NADH}$, and lactate dehydrogenase (10 $U)$.

\section{Phosphorylation of ADP using Carbamoyl Phosphate}

The phosphorylating ability of PC was determined by measuring the amount of ATP production using the hexokinase/glucose-6phosphate dehydrogenase coupled assay. ${ }^{16}$ Specific activities were determined from reactions containing $100 \mathrm{mM}$ Tricine ( $\mathrm{pH} 7.5), 20 \mathrm{mM}$ carbamoyl phosphate, $3.0 \mathrm{mM} \mathrm{MgCl}$, $3.0 \mathrm{mM} \mathrm{MgADP}, 0.25 \mathrm{mM}$ acetylCoA, 0.24 mM NADP, 0.20 mM glucose, glucose-6-phosphate dehydrogenase ( $5 \mathrm{U})$ and hexokinase $(1 \mathrm{U})$.

\section{Bicarbonate-dependent ATPase Activity}

Activities for the bicarbonate-dependent ATPase reaction were determined by measuring the amount of inorganic phosphorus $\left(\mathrm{P}_{\mathrm{i}}\right)$ produced using a glucose-6-phosphate dehydrogenase/phosphoglucomutase/phosphorylase coupled assay system. All assays were performed at $25^{\circ} \mathrm{C}$ in $3 \mathrm{~mL}$ total reaction volumes. Specific activities were determined in triplicate and reactions were initiated by the addition of PC (300-990 $\mu \mathrm{g})$. Reactions for the determination of the $\mathrm{V}_{\max }$ and specific activities contained $100 \mathrm{mM}$ Tricine ( $\mathrm{pH}$ 7.5), $10 \mathrm{mM} \mathrm{HCO}_{3}-, 2.5 \mathrm{mM} \mathrm{MgATP}, 2.5 \mathrm{mM} \mathrm{MgCl}, 0.33$ mM NADP, $0.25 \mathrm{mM}$ acetyl-CoA, $0.2 \mathrm{mM}$ glycogen, $0.20 \mathrm{mM}$ glucose, $5 \mu \mathrm{M}$ a-D-glucose-1-phosphate, glucose-6-phosphate dehydrogenase $(10 \mathrm{U})$, phosphorylase $a(5 \mathrm{U})$, and phosphoglucomutase $(10 \mathrm{U})$.

Biochemistry, Vol 48, No. 20 (May 26, 2009): pg. 4305-4313. DOI. This article is (C) American Chemical Society and permission has been granted for this version to appear in e-Publications@Marquette. American Chemical Society does not grant permission for this article to be further copied/distributed or hosted elsewhere without the express permission from American Chemical Society. 
Oxamate and pyruvate inhibition were determined by measuring the initial velocities of $P_{i}$ formation at varying concentrations of oxamate $(0-20 \mathrm{mM})$ or pyruvate $(0-20 \mathrm{mM})$ and fixed, saturating concentrations of the other reaction components. Oxaloacetate formed from pyruvate carboxylation was immediately converted to malate using malate dehydrogenase $(15 \mathrm{U})$.

\section{Data Analysis}

$\mathrm{V}_{\max }$ and $(\mathrm{V} / \mathrm{K})$ values were determined by fitting velocity versus substrate concentration data to eqn 1 using least-squares nonlinear regression, where $\mathbf{A}$ is the substrate concentration. All least-square fits were performed using FORTRAN programs ${ }^{17}$ and best-fit lines were plotted using SigmaPlot v. 8.0, unless otherwise indicated.

$$
\mathrm{v}=\frac{\mathbf{V}_{\max } \mathbf{A}}{\mathbf{K}_{\mathrm{a}}+\mathbf{A}}
$$

Substrate inhibition data with oxamate or pyruvate for the bicarbonate-dependent ATPase reactions were fitted to eqn 2, where $\mathbf{A}$ is the concentration of pyruvate or oxamate and $\mathrm{K}_{\mathrm{i}}$ is the inhibition constant for the substrate.

$$
\mathrm{v}=\frac{\mathrm{V}_{\mathrm{max}} \mathrm{A}}{\mathrm{K}_{\mathrm{a}}+\mathrm{A}\left(1+\frac{\mathrm{A}}{\mathrm{K}_{\mathrm{i}}}\right)}
$$

Partial inhibition data were fitted to eqn 3 where $\mathbf{I}$ is the concentration of the inhibitor.

$$
\mathrm{v}=\frac{\mathbf{V}_{\max }\left(1+\frac{\mathbf{I}}{\mathbf{K}_{\mathrm{in}}}\right)}{\left(1+\frac{\mathbf{I}}{\mathbf{K}_{\mathrm{id}}}\right)}
$$

Biochemistry, Vol 48, No. 20 (May 26, 2009): pg. 4305-4313. DOI. This article is (C) American Chemical Society and permission has been granted for this version to appear in e-Publications@Marquette. American Chemical Society does not grant permission for this article to be further copied/distributed or hosted elsewhere without the express permission from American Chemical Society. 
NOT THE PUBLISHED VERSION; this is the author's final, peer-reviewed manuscript. The published version may be accessed by following the link in the citation at the bottom of the page.

\section{Results}

\section{Reactions Involving the Carboxyl Transferase Domain}

The activities for pyruvate carboxylation and oxaloacetate decarboxylation, both in the presence and absence of oxamate, were determined for wild-type RePC and several mutant forms of the enzyme, Table 2 and Table 3. With the exception of Lys1119, all other residues targeted for mutagenic studies were located within the CT domain. Lys1119, which is biotinylated at the $\varepsilon-\mathrm{NH}$ position, is located at the C-terminal end of the BCCP domain of RePC. ${ }^{4}$ Mutation of Lys1119 to Gln (K1119Q) generated an intact, tetrameric apoenzyme lacking a covalently attached biotin. ${ }^{18}$

Table 2. Activities for Pyruvate Carboxylation and Oxaloacetate Decarboxylation

\begin{tabular}{|c|c|c|c|c|c|}
\hline & \multicolumn{3}{|c|}{ Pyruvate Carboxylation ${ }^{a}$} & \multicolumn{2}{|c|}{ Full Reverse Reaction b } \\
\hline & $\begin{array}{c}V_{\max } \\
(\mu \mathrm{mol} / \mathrm{mg} \min )\end{array}$ & $\begin{array}{c}(\mathrm{V} / \mathrm{K})^{\mathrm{c}} \\
\left(\mathrm{mM}^{-1} \mathrm{~min}^{-1}\right)\end{array}$ & $\begin{array}{l}\% \text { of } \\
\text { wt } \\
\text { rate }\end{array}$ & $\mathrm{nmol} / \mathrm{mg} \mathrm{mind}$ & $\begin{array}{l}\% \text { of wt } \\
\text { rate }\end{array}$ \\
\hline wild-type & $3.5 \pm 0.2$ & $7.1 \pm 0.9$ & $(100)$ & $5.9 \pm 0.2$ & $(100)$ \\
\hline K1119Q & $N A^{e}$ & NA & NA & NA & NA \\
\hline K718Q & $0.10 \pm 0.08$ & $0.15 \pm 0.02$ & 2.9 & $0.84 \pm 0.04$ & 14 \\
\hline T882A & NA & NA & NA & NA & NA \\
\hline T882S & $0.75 \pm 0.03$ & $1.0 \pm 0.2$ & 21 & $3.06 \pm 0.07$ & 51 \\
\hline T882C & $0.25 \pm 0.04$ & $0.18 \pm 0.03$ & 7.1 & $1.2 \pm 0.2$ & 20 \\
\hline Q844L/S885A & $0.47 \pm 0.07$ & $0.42 \pm 0.08$ & 13 & $3.12 \pm 0.08$ & 53 \\
\hline $\begin{array}{l}\text { aReaction conditi } \\
2.5 \text { mM MgATP, } \\
\text { beaction conditi } \\
\text { mM phosphate, } 0 \\
\text { cPyruvate as vari } \\
\text { dNumber of deter } \\
\text { eNA = No activity }\end{array}$ & $\begin{array}{l}\text { ons: } 100 \mathrm{mM} \text { Tricin } \\
2.5 \mathrm{mM} \mathrm{MgCl}_{2}, 0.25 \\
\text { ons: } 100 \mathrm{mM}^{2} \text { Tricin } \\
.5 \mathrm{mM} \text { oxaloacetat } \\
\text { able substrate. } \\
\text { rminations for spec } \\
\text { / detected. }\end{array}$ & $\begin{array}{l}\text { ne }(\mathrm{pH} 7.5), 25^{\circ} \\
5 \mathrm{mM} \text { acetyl-CoA. } \\
\text { ne }(\mathrm{pH} 7.5), 25^{\circ} \\
\text { te, } 0.25 \mathrm{mM} \text { acet) } \\
\text { cific activities }=3\end{array}$ & $\begin{array}{l}\text { C, } 8 \mathrm{mN} \\
\text { C, } 2 \mathrm{mN} \\
\text { yl-CoA. }\end{array}$ & $\begin{array}{l}\text { M pyruvate, } 10 \mathrm{~m} \\
\mathrm{M} \mathrm{MgCl}_{2}, 2 \mathrm{mM} \mathrm{Mc}\end{array}$ & $\begin{array}{l}\mathrm{M} \mathrm{HCO}_{3}- \\
\operatorname{gADP}, 2\end{array}$ \\
\hline
\end{tabular}

Table 3. Oxaloacetate Decarboxylating Activities in the Presence of Oxamate ${ }^{a}$

$\begin{array}{lcc} & \mathbf{n m o l} / \mathbf{m g ~ m i n}^{\mathbf{b}} & \begin{array}{c}\text { \% of wt } \\ \text { rate }\end{array} \\ \text { wild-type } & 29 \pm 4 & (100) \\ \text { K1119Q } & N A^{c} & \mathrm{NA} \\ \mathbf{K 7 1 8 Q} & 2.1 \pm 0.1 & 7.2 \\ \text { T882A } & \mathrm{NA} & \mathrm{NA} \\ \text { T882S } & 8.7 \pm 0.3 & 30\end{array}$

Biochemistry, Vol 48, No. 20 (May 26, 2009): pg. 4305-4313. DOI. This article is (C) American Chemical Society and permission has been granted for this version to appear in e-Publications@Marquette. American Chemical Society does not grant permission for this article to be further copied/distributed or hosted elsewhere without the express permission from American Chemical Society. 
NOT THE PUBLISHED VERSION; this is the author's final, peer-reviewed manuscript. The published version may be accessed by following the link in the citation at the bottom of the page.

\section{$\mathrm{nmol} / \mathrm{mg} \mathrm{min}^{\mathrm{b}}$}

T882C

Q844L/S885A
$\%$ of wt

rate

$3.3 \pm 0.1$

11

4.7

aReaction conditions: $100 \mathrm{mM}$ Tricine $(\mathrm{pH} 7.5), 25^{\circ} \mathrm{C}, 0.25 \mathrm{mM}$ acetyl-CoA, $3 \mathrm{mM}$ $\mathrm{MgCl}_{2}, 0.5 \mathrm{mM}$ oxaloacetate, $0.5 \mathrm{mM}$ oxamate.

bNumber of determinations $=3$.

${ }^{\mathrm{C}} \mathrm{NA}=$ No activity.

The CT domain mutants primarily exhibited a marked decrease in the maximum activity for pyruvate carboxylation and a similar decrease in the $\mathrm{V} / \mathrm{K}$ values for pyruvate, Table 2 . For wild-type RePC, the $K_{m}$ of pyruvate was determined to be $0.47 \pm 0.04 \mathrm{mM}$. The T882A and $\mathrm{K} 1119 \mathrm{Q}$ mutations had a devastating effect on the catalytic activity of reactions involving the CT domain, completely abolishing pyruvate carboxylating activity. The addition of $10 \mathrm{mM}$ free biotin to the K1119Q catalyzed reaction had no effect on the mutant's ability to carboxylate pyruvate.

Correspondingly, the $\mathrm{K} 1119 \mathrm{Q}$ and $\mathrm{T} 882 \mathrm{~A}$ mutants were also completely inactive for oxaloacetate decarboxylation, both in the presence and absence of oxamate. In the absence of oxamate, oxaloacetate decarboxylation has been shown to be coupled to ATP formation in the BC domain. ${ }^{8}$ This allows the effect of the CT domain mutations on the full reverse reaction to be determined. The wild-type catalyzed rate was approximately $0.2 \%$ of the forward rate, which was somewhat lower than rates observed with PC from other sources. ${ }^{8}$, ${ }^{19} \mathrm{~A}$ significant decrease in the specific activities was observed for all other CT domain mutants, Table 2.

Since oxamate stimulates the partially rate-limiting decarboxylation of carboxybiotin in the CT domain during oxaloacetate decarboxylation, ${ }^{6,8}$ monitoring oxaloacetate decarboxylation in the presence of oxamate allowed the reverse reaction of the CT domain to be assayed independently from the $\mathrm{BC}$ domain reactions, Table 3 . The wild-type enzyme catalyzed reaction occurs at $1.0 \%$ the rate of the pyruvate carboxylation reaction, nearly five-times faster than oxaloacetate decarboxylation coupled to ATP formation. The CT domain mutations appeared to affect the rate of the oxamatestimulated oxaloacetate decarboxylation to a greater extent when compared to the activities of the full reverse reaction. Even a

Biochemistry, Vol 48, No. 20 (May 26, 2009): pg. 4305-4313. DOI. This article is (C) American Chemical Society and permission has been granted for this version to appear in e-Publications@Marquette. American Chemical Society does not grant permission for this article to be further copied/distributed or hosted elsewhere without the express permission from American Chemical Society. 
conservative Threonine to Serine mutation (T882S) caused a considerable decrease in the observed activity (70\%). It is interesting to note that the T882S mutant consistently showed higher activities than the T882C mutant for reactions involving the CT domain.

\section{Reactions Involving Only the Biotin Carboxylase Domain}

A structural analogue of the putative carboxyphosphate intermediate, carbamoyl phosphate, can be used by a variety of biotin dependent carboxylases, including acetyl-CoA carboxylase, ${ }^{20,21}$ to phosphorylate MgADP. The specific activities for wild-type and CT domain mutants of RePC were determined for the phosphorylation of ADP using carbamoyl phosphate, Table 4. The CT domain mutants, with the exception of T882A, all showed a somewhat surprising decrease in their ADP phosphorylating activity. The non-biotinylated mutant, K1119Q, exhibited the least amount of activity while the T882S mutation exhibited only a modest decrease in activity. Remarkably, the T882A mutation increased the activity, as compared to the wild-type enzyme, by 7.5-fold in the absence of biotin and 9.5fold in the presence of $10 \mathrm{mM}$ free biotin.

Table 4. ADP Phosphorylation Activities Using Carbamoyl Phosphate in the Presence and Absence of Free Biotin or Oxamate

\begin{tabular}{|c|c|c|c|c|c|c|}
\hline & $\underset{\min ^{b}}{\mathbf{n m o l} / \mathbf{m g}}$ & $\begin{array}{c}\% \text { of } \\
\text { wt } \\
\text { rate }\end{array}$ & $\begin{array}{c}\text { Biotin (10 } \\
\text { mM) } \\
\text { nmol/mg min }\end{array}$ & $\begin{array}{l}\% \text { of } \\
\text { wt } \\
\text { rate }\end{array}$ & $\begin{array}{c}\text { Oxamate (20 } \\
\mathrm{mM} \text { ) } \\
\mathrm{nmol} / \mathrm{mg} \text { min }\end{array}$ & $\begin{array}{l}\% \text { of } \\
\text { wt } \\
\text { Rate }\end{array}$ \\
\hline wild-type & $17.8 \pm 0.5$ & $(100)$ & $22.5 \pm 0.4$ & $(100)$ & $32.4 \pm 0.4$ & (100) \\
\hline K1119Q & $0.184 \pm 0.03$ & 1.03 & $18.2 \pm 0.6$ & 81 & $0.19 \pm 0.04$ & 0.57 \\
\hline K718Q & $9.3 \pm 0.2$ & 52 & $3.6 \pm 0.1$ & 16 & $10.25 \pm 0.06$ & 31 \\
\hline T882A & $133 \pm 3$ & 747 & $317.2 \pm 0.3$ & 1408 & $107 \pm 5$ & 303 \\
\hline T882S & $12.6 \pm 0.2$ & 71 & $43.3 \pm 0.1$ & 192 & $9.6 \pm 0.2$ & 30 \\
\hline T882C & $5.1 \pm 0.1$ & 29 & $11.2 \pm 0.3$ & 49 & $4.8 \pm 0.3$ & 15 \\
\hline Q844L/S885A & $5.7 \pm 0.4$ & 32 & $14.4 \pm 0.2$ & 64 & $18.6 \pm 0.4$ & 57 \\
\hline
\end{tabular}

aReaction conditions: $100 \mathrm{mM}$ Tricine (pH 7.5), $25^{\circ} \mathrm{C}, 2 \mathrm{mM}$ MgADP, $10 \mathrm{mM}$ carbamoyl phosphate, $2 \mathrm{mM} \mathrm{MgCl}, 0.25 \mathrm{mM}$ acetyl-CoA.

bNumber of determinations $=3$.

While the covalently attached biotin is not directly involved in the ADP phosphorylation reaction, ${ }^{3}$ the presence of free biotin has a stimulatory effect on the rates of BC domain reactions in PC from other sources. ${ }^{3,16,18,22}$ Therefore, the activities of the mutant and wild-type

Biochemistry, Vol 48, No. 20 (May 26, 2009): pg. 4305-4313. DOI. This article is (c) American Chemical Society and permission has been granted for this version to appear in e-Publications@Marquette. American Chemical Society does not grant permission for this article to be further copied/distributed or hosted elsewhere without the express permission from American Chemical Society. 
forms of RePC were also determined with $10 \mathrm{mM}$ free biotin, Table 4. With the exception of the K718Q mutant, which showed a slight inhibitory effect, biotin stimulated the activities to varying degrees. Similar to the T882A mutant, the activity of the T882S mutant in the presence of biotin surpassed the wild-type RePC activity. The activity of $\mathrm{K} 1119 \mathrm{Q}$, which was only $1 \%$ of the wild-type enzyme activity in the absence of biotin, was almost completely restored to wild-type levels with the addition of $10 \mathrm{mM}$ free biotin.

Previous studies with chicken liver PC indicated that oxamate has a partial inhibitory effect on the ADP phosphorylation reaction and is a noncompetitive inhibitor with respect to carbamoyl phosphate. ${ }^{16}$ Specific activities of the RePC catalyzed reactions, using both the CT domain mutants and wild-type, were determined in the presence of 20 mM of oxamate, Table 4. There was no discernable effect on phosphorylating activity for the $\mathrm{K} 1119 \mathrm{Q}$ mutant and a slight inhibition of the activities for all of the Thr882 mutants. Contrary to previous studies, oxamate stimulated the wild-type RePC activity for ADP phosphorylation nearly 2 -fold.

Table 5 shows the specific activities of wild-type and CT domain mutants for the bicarbonate-dependent ATPase reaction. In order to examine only the first partial reaction of pyruvate carboxylation, specific activities were initially measured in the absence of pyruvate and the enzymatic activity was assayed by determining the amount of $P_{i}$ formed, thus eliminating any possible effects pyruvate had on the activities. Similar to the ADP phosphorylation reaction, all of the CT domain mutants demonstrated some level of activity, with the series of Thr882 mutants exhibiting a 2-3.5 fold increase in activity as compared to the wild-type enzyme. All other CT domain mutants showed a decrease in their ability to catalyze ATP cleavage. As in the ADP phosphorylation reaction, the addition of $10 \mathrm{mM}$ free biotin promoted the bicarbonate-dependent ATPase reaction in both wildtype and mutant forms of the enzyme, Table 5, similar to the synergistic effects observed with acetyl-CoA carboxylase. ${ }^{23}$ Once again, the addition of biotin virtually restored the activity of the K1119Q mutant to wild-type enzyme levels. From the specific activities, biotin appeared to have a greater stimulatory effect on the ATP cleavage than on the ADP phosphorylation with the wild-type enzyme, Table 4.

Biochemistry, Vol 48, No. 20 (May 26, 2009): pg. 4305-4313. DOI. This article is (c) American Chemical Society and permission has been granted for this version to appear in e-Publications@Marquette. American Chemical Society does not grant permission for this article to be further copied/distributed or hosted elsewhere without the express permission from American Chemical Society. 
NOT THE PUBLISHED VERSION; this is the author's final, peer-reviewed manuscript. The published version may be accessed by following the link in the citation at the bottom of the page.

Table 5. Bicarbonate-Dependent ATPase Activities in the Presence and Absence of Free Biotin or Oxamate ${ }^{a}$

\begin{tabular}{|c|c|c|c|c|c|c|}
\hline & $\underset{\min ^{b}}{\mathrm{nmol} / \mathrm{mg}}$ & $\begin{array}{l}\% \text { of } \\
\text { wt } \\
\text { rate }\end{array}$ & $\begin{array}{c}\text { Biotin (10 } \\
\text { mM) } \\
\text { nmol/mg min }\end{array}$ & $\begin{array}{l}\% \text { of } \\
\text { wt } \\
\text { rate }\end{array}$ & $\begin{array}{c}\text { Oxamate (20 } \\
\mathrm{mM} \text { ) } \\
\mathrm{nmol} / \mathrm{mg} \mathrm{min}\end{array}$ & $\begin{array}{l}\% \text { of } \\
\text { wt } \\
\text { rate }\end{array}$ \\
\hline wild-type & $2.02 \pm 0.01$ & $(100)$ & $5.21 \pm 0.04$ & $(100)$ & $12.8 \pm 0.04$ & $(100)$ \\
\hline K1119Q & $0.32 \pm 0.05$ & 15 & $4.85 \pm 0.07$ & 92 & $0.33 \pm 0.06$ & 1.7 \\
\hline K718Q & $1.76 \pm 0.04$ & 87 & $1.32 \pm 0.01$ & 25 & $7.89 \pm 0.09$ & 52 \\
\hline T882A & $7.20 \pm 0.08$ & 356 & $25.2 \pm 0.2$ & 483 & $2.34 \pm 0.05$ & 9.5 \\
\hline T8825 & $4.5 \pm 0.1$ & 222 & $10.3 \pm 0.1$ & 197 & $3.79 \pm 0.02$ & 18 \\
\hline T882C & $4.3 \pm 0.2$ & 212 & $8.31 \pm 0.04$ & 160 & $3.32 \pm 0.07$ & 19 \\
\hline Q844L/S885A & $1.04 \pm 0.02$ & 51 & $3.75 \pm 0.02$ & 72 & $9.87 \pm 0.2$ & 58 \\
\hline
\end{tabular}

aReaction conditions: $100 \mathrm{mM}$ Tricine $(\mathrm{pH} 7.5), 25^{\circ} \mathrm{C}, 10 \mathrm{mM} \mathrm{HCO}_{3}{ }^{-}, 2.5 \mathrm{mM} \mathrm{MgATP}$, $2.5 \mathrm{mM} \mathrm{MgCl}, 0.25 \mathrm{mM}$ acetyl-CoA

bNumber of determinations $=3$.

To determine if oxamate had an effect on the bicarbonatedependent ATPase reaction, specific activities were initially determined in the presence of $20 \mathrm{mM}$ oxamate, Table 5. There was an appreciable stimulatory effect on the activities for wild-type RePC, as well as for the $\mathrm{K} 718 \mathrm{Q}$ and $\mathrm{Q} 884 \mathrm{~L} / \mathrm{S} 885 \mathrm{~A}$ mutants. While oxamate had no effect on the rate of the $\mathrm{K} 1119 \mathrm{Q}$ catalyzed reaction, a strong inhibitory effect was observed for all three of the Thr882 mutants.

Initial rates of $P_{i}$ formation at varying concentrations of oxamate (0-20 mM) for wild-type, $\mathrm{K} 1119 \mathrm{Q}$ (with $10 \mathrm{mM}$ of free biotin) and T882A catalyzed reactions were determined in an attempt to elucidate the origin of oxamate stimulation and inhibition observed for the bicarbonate-dependent ATPase reaction, Figure 1. At low concentrations, oxamate stimulated the release of $P_{i}$ in the wild-type catalyzed reaction but eventually exhibited substrate inhibition at high concentrations. The initial rates were fitted to eqn 2 , from which an inhibition constant of $\mathrm{K}_{\mathrm{i}}=10.1 \pm 0.1 \mathrm{mM}$ for oxamate was determined, Table 6 . Even with the apparent inhibition at increasing concentrations of oxamate, the rate of the wild-type catalyzed ATP cleavage was stimulated almost 20 -fold. On the other hand, oxamate partially inhibited the bicarbonate-dependent ATPase reaction catalyzed by T882A. The initial rates of $P_{i}$ formation vs. oxamate concentrations were satisfactorily described by eqn 3 , and an oxamate dissociation constant of $1.0 \pm 0.2 \mathrm{mM}$ was determined. Interestingly, even in the presence of $10 \mathrm{mM}$ free biotin and concentrations of oxamate where inhibition was observed for the other enzyme forms

Biochemistry, Vol 48, No. 20 (May 26, 2009): pg. 4305-4313. DOI. This article is (c) American Chemical Society and permission has been granted for this version to appear in e-Publications@Marquette. American Chemical Society does not grant permission for this article to be further copied/distributed or hosted elsewhere without the express permission from American Chemical Society. 
(20 $\mathrm{mM})$, oxamate had no appreciable affect on the ability of the K1119Q mutant to cleave ATP.
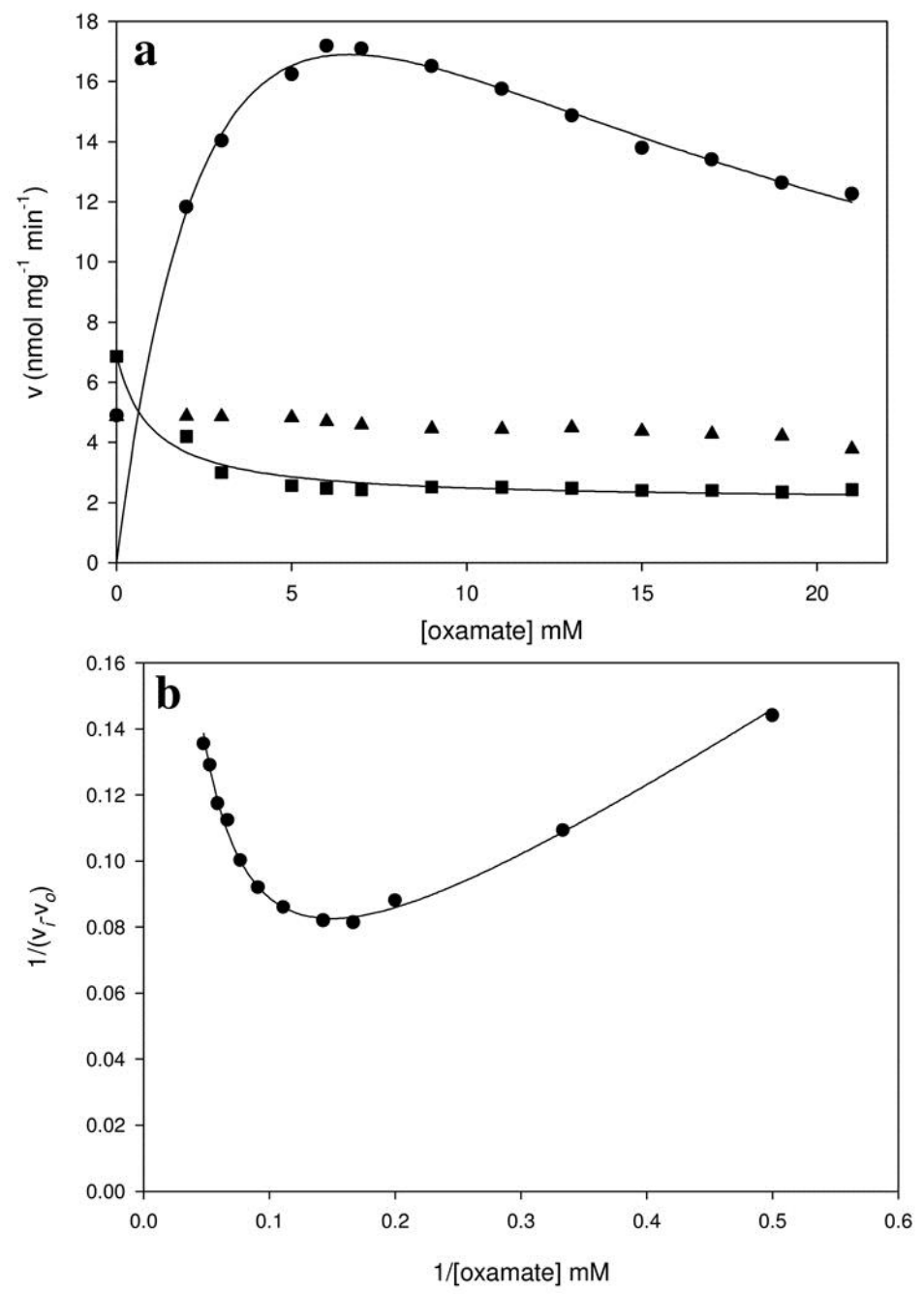

Figure 1. Oxamate inhibition of the bicarbonate-dependent ATPase reaction catalyzed by wild-type $(\bullet), \mathrm{K} 1119 \mathrm{Q}(\boldsymbol{\Delta})$ and T882A ( $\bullet$ ) RePC. (a) Initial rates were determined and data for the wild-type enzyme were fitted to the equation for substrate inhibition (eqn 2), omitting the initial data point for zero oxamate concentration. The partial inhibition data observed for the T882A mutant were fitted to eqn 3. (b) Reciprocal plot of the initial rates vs. oxamate concentration for the wild-type enzyme where $v_{o}$ is the initial rate in the absence of oxamate and $v_{i}$ is the rate determined in the presence of oxamate.

Table 6. Kinetic parameters for pyruvate and oxamate substrate inhibition of the wild-type catalyzed bicarbonate-dependent ATPase reaction

\begin{tabular}{|c|c|c|c|c|}
\hline & $\begin{array}{c}V_{\max } \\
(\mathrm{nmol} / \mathrm{mg} \min )\end{array}$ & $\begin{array}{c}K_{m} \\
(\mathbf{m M})\end{array}$ & $\begin{array}{c}V / K^{c} \\
\left(\mu M^{-1} \min ^{-1}\right)\end{array}$ & $\begin{array}{c}K_{i} \\
(m M)\end{array}$ \\
\hline Pyruvate a & $37 \pm 2$ & $1.0 \pm 0.1$ & $36 \pm 2$ & $10 \pm 1$ \\
\hline
\end{tabular}

Biochemistry, Vol 48, No. 20 (May 26, 2009): pg. 4305-4313. DOI. This article is (C) American Chemical Society and permission has been granted for this version to appear in e-Publications@Marquette. American Chemical Society does not grant permission for this article to be further copied/distributed or hosted elsewhere without the express permission from American Chemical Society. 
NOT THE PUBLISHED VERSION; this is the author's final, peer-reviewed manuscript. The published version may be accessed by following the link in the citation at the bottom of the page.

\section{$\mathrm{V}_{\max }$
$(\mathbf{n m o l} / \mathbf{m g} \mathbf{m i n})$ \\ $K_{\mathbf{m}}$ \\ ( $\mathrm{mM})$ \\ $\mathrm{V} / \mathrm{K}^{\mathrm{c}}$
$\left(\boldsymbol{\mu \mathrm { M } ^ { - 1 }} \mathbf{m i n}^{-1}\right)$ \\ $\mathbf{K}_{\mathbf{i}}$ \\ $(\mathbf{m M})$}

$4.1 \pm 0.5$

$9.2 \pm 0.4$

Oxamate b

$37 \pm 2$

7.5), $25^{\circ} \mathrm{C}, 10 \mathrm{mM} \mathrm{HCO}_{3}{ }^{-}, 2.5 \mathrm{mM} \mathrm{MgATP}$,

Reaction conditions: $100 \mathrm{mM}$ Tricine
$2.5 \mathrm{mM} \mathrm{MgCl}$
$2,0.25 \mathrm{mM}$ acetyl-CoA.

a $0-20 \mathrm{mM}$ pyruvate

b0-20 mM pyruvate. Data fitted to eqn 2.

$\mathrm{C} / \mathrm{K}$ values determined for either pyruvate or oxamate.

Given that the bicarbonate-dependent ATPase reaction is the first step for the overall carboxylation of pyruvate, the effect of pyruvate on the initial rates of $\mathrm{P}_{\mathrm{i}}$ formation were determined for the wild-type enzyme, as well as the T882A and K1119Q (with $10 \mathrm{mM}$ free biotin) catalyzed reactions, Figure 2 . Being the natural substrate, pyruvate stimulated the release of $\mathrm{P}_{i}$ to a greater extent than oxamate in wild-type catalyzed reaction. Similar to the effect of oxamate, substrate inhibition by pyruvate was observed at high concentrations and the $K_{i}$ value for pyruvate $\left(K_{i} 10.2 \pm 0.1 \mathrm{mM}\right)$ was comparable to that for oxamate under similar conditions, Table 6. Pyruvate also inhibited the T882A catalyzed bicarbonate-dependent ATPase reaction in a manner similar to the partial inhibition by oxamate, Table 7 . In fact, kinetic parameters in the presence of either inhibitor were nearly identical, with the apparent dissociation constant for pyruvate equal to $0.8 \pm 0.1 \mathrm{mM}$. Pyruvate also had no effect on the initial rate of ADP formation for the $\mathrm{K} 1119 \mathrm{Q}$ mutant in the presence of $10 \mathrm{mM}$ free biotin.

Biochemistry, Vol 48, No. 20 (May 26, 2009): pg. 4305-4313. DOI. This article is (C) American Chemical Society and permission has been granted for this version to appear in e-Publications@Marquette. American Chemical Society does not grant permission for this article to be further copied/distributed or hosted elsewhere without the express permission from American Chemical Society. 
NOT THE PUBLISHED VERSION; this is the author's final, peer-reviewed manuscript. The published version may be accessed by following the link in the citation at the bottom of the page.

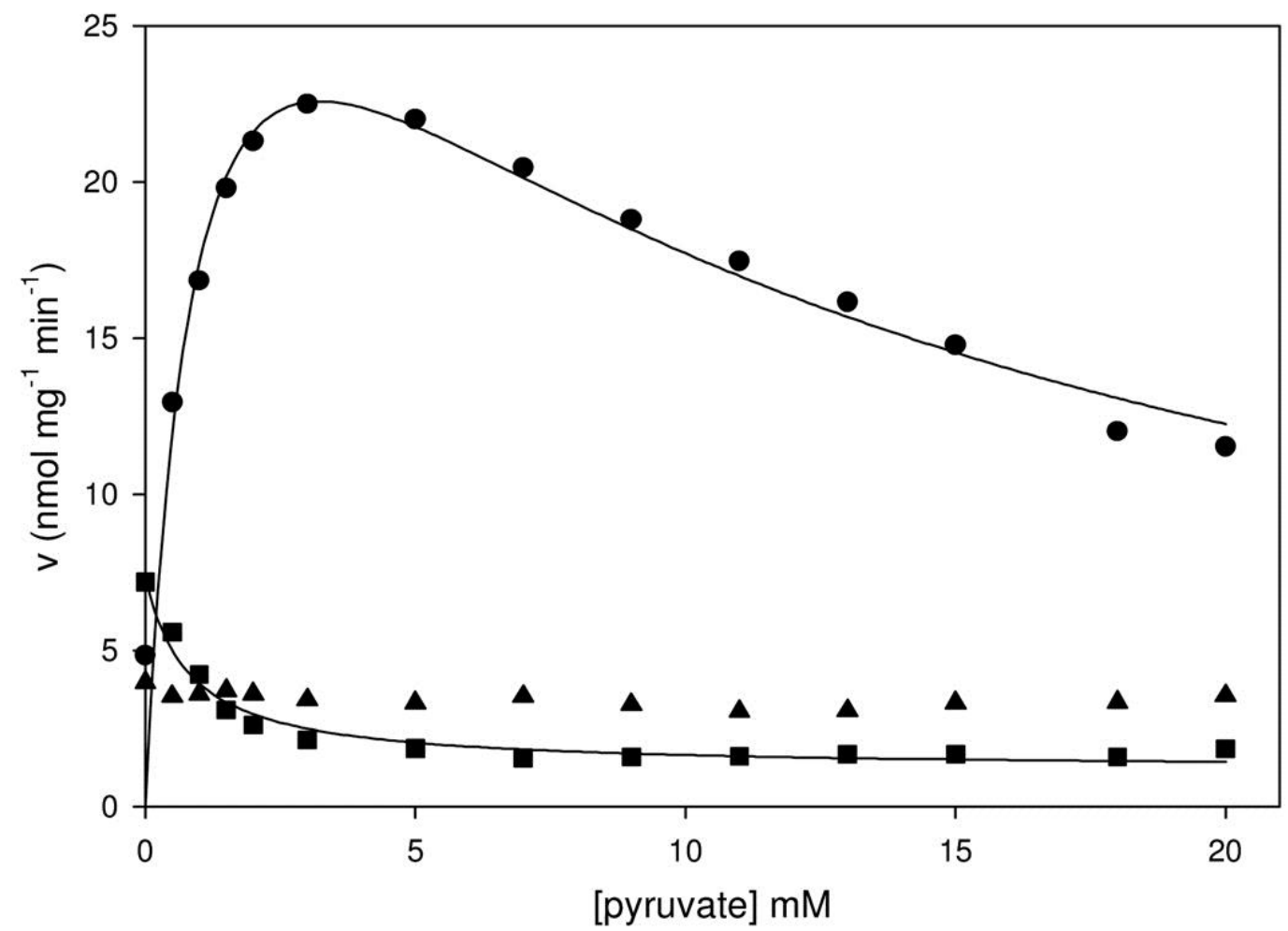

Figure 2. Pyruvate inhibition of the bicarbonate-dependent ATPase reaction catalyzed by K1119Q ( $\mathbf{\Lambda})$, T882A ( $\bullet$ ) and wild-type enzyme (•). Data were fitted to eqn 2 for the wild-type catalyzed reaction (omitting the initial point for oxamate concentration equal to zero) and data for partial inhibition of the T882A catalyzed reaction were fitted to eqn 3.

Table 7. Inhibition parameters for oxamate and pyruvate using the T882A mutant for the bicarbonate-dependent ATPase reaction

$\begin{array}{lcccc} & \mathbf{V}_{\max }(\mathbf{n m o l} / \mathbf{m g} \mathbf{m i n}) & \mathbf{K}_{\text {inum }}(\mathbf{m M}) & \mathbf{K}_{\text {iden }}(\mathbf{m M}) & \mathbf{K}_{\text {ideN }} / \mathbf{K}_{\text {iNUM }} \\ \text { Pyruvate }^{a} & 7.8 \pm 0.3 & 4.9 \pm 0.1 & 0.8 \pm 0.1 & 0.16 \pm 0.02 \\ \text { Oxamate }^{b} & 6.8 \pm 0.2 & 3.4 \pm 0.9 & 1.0 \pm 0.2 & 0.29 \pm 0.02\end{array}$

Reaction conditions: $100 \mathrm{mM}$ Tricine $(\mathrm{pH} 7.5), 25^{\circ} \mathrm{C}_{1} 10 \mathrm{mM} \mathrm{HCO}_{3}{ }^{-}, 2.5 \mathrm{mM} \mathrm{MgATP}$, $2.5 \mathrm{mM} \mathrm{MgCl}, 0.25 \mathrm{mM}$ acetyl-CoA.

a $0-20 \mathrm{mM}$ pyruvate

bo-20 mM pyruvate. Data fitted to eqn 3.

\section{Discussion}

Interpretation of previous mutagenic studies of residues residing in the CT domain of PC were hampered by a lack of sufficient crystal structure data and most residues targeted for mutagenesis were selected based on sequence conservation with the homologous $5 \mathrm{~S}$ subunit of transcarboxylase. ${ }^{10}$ However, structural descriptions of the RePC holoenzyme, ${ }^{4}$ the Staphylococcus aureus PC holoenzyme ${ }^{12}$ and

Biochemistry, Vol 48, No. 20 (May 26, 2009): pg. 4305-4313. DOI. This article is (C) American Chemical Society and permission has been granted for this version to appear in e-Publications@Marquette. American Chemical Society does not grant permission for this article to be further copied/distributed or hosted elsewhere without the express permission from American Chemical Society. 
NOT THE PUBLISHED VERSION; this is the author's final, peer-reviewed manuscript. The published version may be accessed by following the link in the citation at the bottom of the page.

the CT domain of human PC $^{12}$ have revealed several previously unrecognized residues ideally positioned in the CT domain active site to participate in biotin enolate stabilization and to facilitate both proton and carboxyl transfer. The kinetic data obtained from the focused mutagenic study of this current work allows for a more accurate description of the carboxyl transfer mechanism in the CT domain of RePC.

\section{Possible catalytic relevance for a highly conserved carbamylated Lysine- Lys718}

The crystal structure of 5S-pyruvate transcarboxylase complex revealed the presence of a highly conserved carbamylated Lysine positioned near the cationic metal center. ${ }^{10}$ The equivalent Lys718 was also carbamylated in the RePC and hPC structure and coordinated the cationic metal center in the CT domain active site. ${ }^{4,12}$ Mutations of the corresponding Lysine in $B$. thermodenitrificans $P C$ resulted in significant, but not complete, reductions in the catalytic activity for pyruvate carboxylation. ${ }^{11}$ Similar effects were observed in the specific activities for the $\mathrm{K} 718 \mathrm{Q}$ mutant form of RePC, which retained only $3 \%$ of pyruvate carboxylating ability and $14 \%$ of decarboxylating ability as compared to wild-type RePC activities. These kinetic studies indicate that, while important, Lys718 is not absolutely essential to catalysis. Previously, Lys718 was proposed to be significant for inducing the decarboxylation of biotin through interactions of the $\varepsilon-\mathrm{NH}_{3}{ }^{+}$with the ureido oxygen of biotin ${ }^{11}$ but structural data from RePC ${ }^{4}$ and $\mathrm{hPC}^{12}$ position Lys718 greater than $7 \AA$ away from the $N_{1}$-position of biotin. Furthermore, inhibition of the $\mathrm{K} 718 \mathrm{Q}$ specific activities for the ADP phosphorylation and $\mathrm{HCO}_{3}$-dependent ATPase reactions by oxamate is akin to that observed for the T882A mutant, suggesting that the K718Q mutation had a greater effect on the enzyme's ability to facilitate carboxyl transfer than it did on the enzyme's ability to stabilize the biotin enolate intermediate. While coordination to the metal center in the several available structures ${ }^{4,10,12}$ suggests one possible role for Lys718 is to position the requisite metal ion in the CT domain, it is interesting to note that in crystal structures of hPC and the homologous $5 S$ transcarboxylase containing pyruvate ${ }^{10,12}$ in the active site the lysine is carbamylated, while it is not carbamylated in $5 \mathrm{~S}$ transcarboxylase structure containing oxaloacetate. ${ }^{10}$ Although the

Biochemistry, Vol 48, No. 20 (May 26, 2009): pg. 4305-4313. DOI. This article is (c) American Chemical Society and permission has been granted for this version to appear in e-Publications@Marquette. American Chemical Society does not grant permission for this article to be further copied/distributed or hosted elsewhere without the express permission from American Chemical Society. 
carbamylated Lys718 in RePC may be an artifact of the crystallization conditions or may simply be involved in the coordination and stabilization of the metal center in the active site, it is also possible to envision a mechanism where $\mathrm{CO}_{2}$ combines with Lys718 during the proton transfer between pyruvate and biotin as a way to prevent diffusion from the active site.

\section{Stabilization of the biotin enolate intermediate- GIn844 and Ser885}

The initial decarboxylation of carboxybiotin in the CT domain is proposed to generate a biotin enolate intermediate prior to protonation. ${ }^{2,5} \mathrm{GIn} 844$, Ser885 and the a-NH $\mathrm{NH}_{3}$ of Lys886 comprise a highly conserved triad of residues positioned to facilitate this decarboxylation by promoting the formation of the anionic intermediate. ${ }^{12}$ The developing negative charge at the ureido oxygen would be best stabilized via the formation of hydrogen-bonds at tetrahedral angles with this triad of residues and the ureido oxygen, Figure 3. The effect of the Q884L/S885A double mutation is most apparent in the specific activities determined for the oxamate-induced decarboxylation of oxaloacetate, where carboxybiotin decarboxylation is proposed to be partially rate limiting. ${ }^{6,8}$ Mutations of residues responsible for assisting in carboxybiotin decarboxylation would be expected to impede the partial reverse reaction by reducing the enzyme's ability to stabilize the transition state. Indeed, these mutations result in a 20 -fold decrease in oxaloacetate decarboxylating ability. The stimulation of the specific activities of the ADP phosphorylation and bicarbonate-dependent ATPase reaction in the presence of $20 \mathrm{mM}$ oxamate further suggests that these residues play a key role in biotin stabilization and binding rather than being directly involved in the carboxyl/proton transfer.

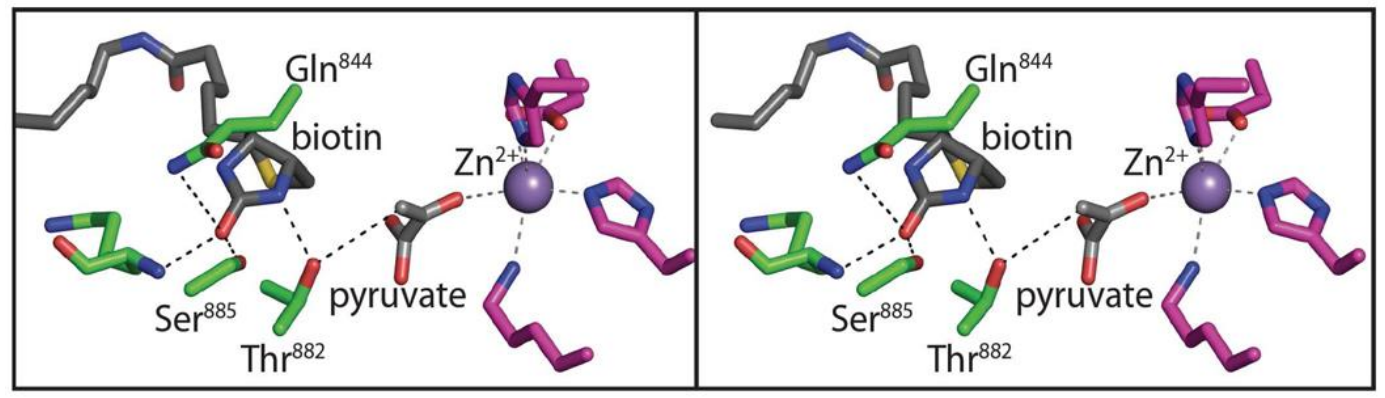

Biochemistry, Vol 48, No. 20 (May 26, 2009): pg. 4305-4313. DOI. This article is (C) American Chemical Society and permission has been granted for this version to appear in e-Publications@Marquette. American Chemical Society does not grant permission for this article to be further copied/distributed or hosted elsewhere without the express permission from American Chemical Society. 
NOT THE PUBLISHED VERSION; this is the author's final, peer-reviewed manuscript. The published version may be accessed by following the link in the citation at the bottom of the page.

Figure 3. Stereo view of the CT active site of SaPC. The position of biotin and pyruvate is shown in the active site of chain $C$ from the $X$-ray crystal structure of Staphylococcus aureus (PDB accession code 3BG5; 12). For clarity, residues are numbered according to their position in RePC. The residues chelating the active site metal in SaPC are shown in pink and correspond to residues Lys718, His747, His749, and Asp549 in RePC. The arrangement of pyruvate, with only the carbonyl oxygen coordinated to the cationic metal center, may possibly be a nonproductive binding mode as the carboxyl group is presumably coordinated in the active orientation.

\section{Subunit communication mediated by the covalently attached biotin- Lys1119}

Given that the tethered biotin moiety acts as the mobile carboxyl carrier between the BC and CT domains of two adjacent subunits, it was no surprise that the $\mathrm{K} 1119 \mathrm{Q}$ mutation completely abolished catalytic activity in the $\mathrm{CT}$ domain and significantly retarded the rates of reactions occurring in the $\mathrm{BC}$ domain. Comparable to effects observed for the K1112A mutant of $B$. thermodenitrificans $\mathrm{PC}^{18}$ the presence of $10 \mathrm{mM}$ free biotin nearly restored the catalytic activity of the K1119Q mutant for MgADP phosphorylation with carbamoyl phosphate and the bicarbonate-dependent ATPase reaction to that observed in wild-type RePC. The stimulation of the BC domain reactions by free biotin, which has been reported for $\mathrm{PC}^{16,22}$ and acetylCoA carboxylase, ${ }^{23}$ could be due in part to conformational changes induced by the presence of biotin. Interestingly, the presence of pyruvate and oxamate had no effect on the rates of the K1119Q catalyzed phosphorylation of MgADP and cleavage of ATP, Figure 1 and Figure 2 . This is in stark contrast to the effects pyruvate and oxamate on both the T882A mutant and wild-type RePC, which exhibited a partial inhibitory and stimulatory affect on the rates of the BC domain reactions, respectively. This, coupled with the observation that the mutations of the CT domain have an effect on the specific activities for reactions of the $\mathrm{BC}$ domains in the biotinylated enzymes, strongly suggests that the BCCP domain-tethered biotin of RePC is responsible for coordinating catalysis between the $\mathrm{BC}$ and $\mathrm{CT}$ domains on two opposing polypeptide chains. This intersubunit coordination is most likely mediated through the occupancy of the catalytic domains by the tethered biotin.

More intriguing is the lack of catalytic activity in the CT domain for the K1119Q mutant, even in the presence of 10-20 mM of free

Biochemistry, Vol 48, No. 20 (May 26, 2009): pg. 4305-4313. DOI. This article is (C) American Chemical Society and permission has been granted for this version to appear in e-Publications@Marquette. American Chemical Society does not grant permission for this article to be further copied/distributed or hosted elsewhere without the express permission from American Chemical Society. 
biotin. The SaPC structure revealed several hydrogen bonding interactions between the BCCP domain and the funnel leading to the CT domain active site which appear to facilitate the placement of the tethered biotin in a catalytically productive conformation. ${ }^{12}$ While these interactions may aid the binding and positioning of the BCCP domain, they may also hinder the movement of free biotin into the CT domain, resulting in the lack of carboxylating and decarboxylating activities observed for the non-biotinylated apoenzymes of RePC and PC from $B$. thermodenitrificans. ${ }^{18}$

\section{Proton shuttling between pyruvate and biotin- Thr882}

One of the most surprising revelations of the SaPC and hPC crystal structures was the location of a strictly conserved Threonine (Thr882) residue situated directly between biotin and pyruvate in the CT active site. ${ }^{12}$ Interacting with the $\mathrm{N}_{1}$-position of the tethered biotin and only $4 \AA$ from the methyl group of pyruvate, Figure 3 , the positioning of this crucial residue strongly suggests a carboxyl transfer mechanism where proton shuttling from pyruvate to biotin occurs through hydrogen-bonding interactions with Thr882, Scheme 2. The complete abolition of carboxylating and decarboxylating activities and retention of ADP phosphorylation and ATP cleavage activities with the T882A mutant is some of the most compelling evidence supporting the proposed mechanism.

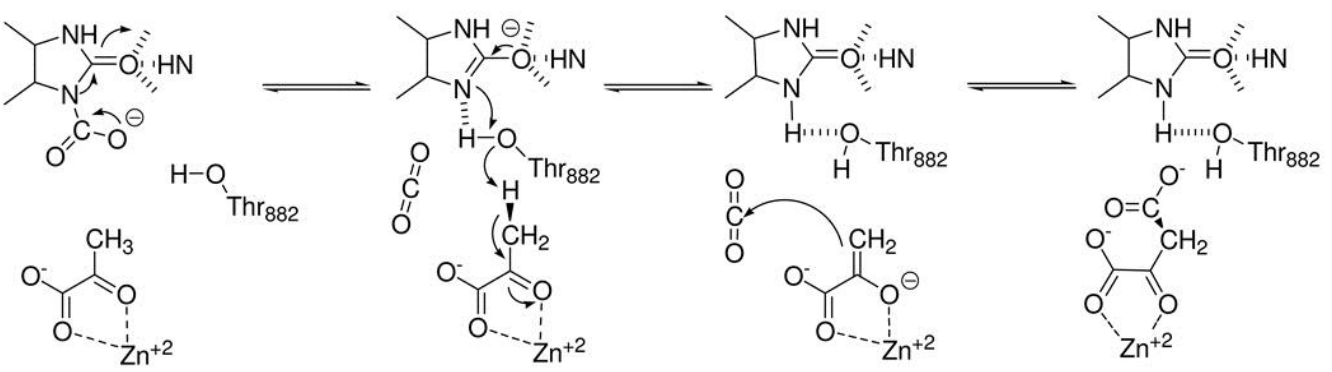

Scheme 2. Proposed mechanism for proton and carboxyl transfer in the CT domain.

It stands to reason from the crystal structures of SaPC and $\mathrm{hPC}^{12}$ that the hydrogen-bonding interactions between the hydroxyl group of Thr882 and the $\mathrm{N}_{1}$-position of the tethered biotin in wild-type RePC may aid in establishing an equilibrium between the occupancy of the $\mathrm{BC}$ and $\mathrm{CT}$ domains by biotin, even in the absence of CT domain substrates. Since the T882A mutant would be unable to form

Biochemistry, Vol 48, No. 20 (May 26, 2009): pg. 4305-4313. DOI. This article is (c) American Chemical Society and permission has been granted for this version to appear in e-Publications@Marquette. American Chemical Society does not grant permission for this article to be further copied/distributed or hosted elsewhere without the express permission from American Chemical Society. 
hydrogen-bonding interactions, a resulting shift in the biotin occupancy equilibrium would favor the placement of biotin in the $\mathrm{BC}$ domain in the absence of CT domain substrates. The increased concentration of biotin in the $\mathrm{BC}$ domain would explain the astonishing increase in activity for the T882A catalyzed phosphorylation of MgADP with carbamoyl phosphate and bicarbonate-dependent ATPase reactions. Moreover, the T882A mutant, which exhibited a 7-fold rate increase, as compared to the wild-type enzyme, showed an even greater 10-13 fold increase in specific activities with the addition of 5-10 mM of free biotin for the ADP phosphorylation reaction, further suggesting that the presence of biotin has a marked effect on the rate of the T882A catalyzed reactions of the $\mathrm{BC}$ domain.

Further evidence that the Thr882 residue is essential for the proton transfer in the CT domain mechanism is discerned from the partial inhibition of the T882A catalyzed bicarbonate-dependent ATPase reaction by oxamate and pyruvate in the presence of acetyl$\mathrm{CoA}$, Figure 1 and Figure 2. Both oxamate and pyruvate trigger the translocation of carboxybiotin from the BC domain to the CT domain, shifting the equilibrium to favor the placement of biotin in the CT domain. ${ }^{24}$ When the CT domain is functioning properly, carboxyl transfer and the subsequent release of products allows for the return of the tethered biotin to the BC domain. Since the T882A mutant does not facilitate the proton transfer from pyruvate, the formation and release of the carboxylated products is prevented and the tethered biotin remains in the CT domain. In fact, the initial rates of $P_{i}$ formation of the T882A catalyzed ATP cleavage in the presence of oxamate and pyruvate are comparable to, and in some cases less than, the rates of the non-biotinylated $\mathrm{K} 1119 \mathrm{Q}$ mutant, suggesting that at high concentrations of the CT domain substrates there is a complete removal of biotin from the $\mathrm{BC}$ domain active sites. Complete inhibition is not observed in the T882A catalyzed ATP cleavage since the reaction can occur in the absence of biotin, albeit at a much slower rate. $2,16,22$ Together, the partial inhibition of the ATP cleavage in the presence of CT domain substrates and rate acceleration in the absence of pyruvate and oxamate for the T882A catalyzed reactions is additional evidence supporting the vital role of Thr882 in the proposed proton transfer mechanism.

Biochemistry, Vol 48, No. 20 (May 26, 2009): pg. 4305-4313. DOI. This article is (c) American Chemical Society and permission has been granted for this version to appear in e-Publications@Marquette. American Chemical Society does not grant permission for this article to be further copied/distributed or hosted elsewhere without the express permission from American Chemical Society. 
The decreased activities for the carboxylation and decarboxylation reactions catalyzed by the T882S and T882C mutants also gives credence to the role of the Thr882 residue in the carboxyl transferase mechanism. While these mutations have not completely disrupted the enzyme's ability to facilitate proton transfer from pyruvate to biotin, the specific activities indicate that the CT domain is not fully functioning. Geometry differences in the conservative T882S mutation could explain the observed decrease in the CT domain activity, Table 2 and Table 3 . The pKa of the thiol group ( 6-9) in the T882C mutant is significantly lower than that of the hydroxyl group of Serine $(\sim 10)$ or Threonine $(\sim 13)$, leading to a decreased ability in generating the enolpyruvate intermediate. The weak general acid/base character of Cysteine ${ }^{25}$ still allows for the T882C mutant to retain catalytic activity for reactions involving the CT domain, albeit at a consistently lower rate than the T882S mutant.

In summary, the overall proposed reaction mechanism, Scheme 2 , is initiated by decarboxylation of carboxybiotin, facilitated by the stabilization of the anionic enol intermediate through hydrogenbonding interactions at the ureido oxygen with GIn844, Ser885, and the backbone amide of Lys866, while the crucial Thr882, initially acting as a general acid in the active site, protonates biotin at the $\mathrm{N}_{1}$ position. An out-of-plane distortion of the carboxyl group of carboxybiotin may further assist the decarboxylation. The coordination of pyruvate to a Lewis acid metal center aids in increasing the acidity of the protons of the methyl group, allowing for Thr882 to act as the general base responsible for abstracting a proton from pyruvate to generate the enol-pyruvate intermediate. In this way, Thr882 acts as both the required active site general acid and base, ${ }^{5}$ shuttling a proton from pyruvate to biotin prior to pyruvate carboxylation. The proton shift may in fact be concerted, so that an unstable Threonine alkoxide intermediate is avoided. $\mathrm{pH}$ profiles for the oxaloacetate decarboxylation, in the presence and absence of oxamate, catalyzed by chicken liver pyruvate carboxylase ${ }^{8}$ suggest that the pKa of the residue involved in general acid/base catalysis lies outside the $\mathrm{pH}$ range examined (5-9), further supporting the role of Thr882 ( $\mathrm{pKa}$ 13) in facilitating the proton transfer in the CT domain.

Several other enzymes, including cytochrome $\mathrm{P} 450^{26}$ and yeast pyruvate kinase, ${ }^{27}$ are also thought to utilize Threonine residues for

Biochemistry, Vol 48, No. 20 (May 26, 2009): pg. 4305-4313. DOI. This article is (C) American Chemical Society and permission has been granted for this version to appear in e-Publications@Marquette. American Chemical Society does not grant permission for this article to be further copied/distributed or hosted elsewhere without the express permission from American Chemical Society. 
NOT THE PUBLISHED VERSION; this is the author's final, peer-reviewed manuscript. The published version may be accessed by following the link in the citation at the bottom of the page.

general acid-base catalysis. The reaction mechanism and catalytic roles assigned to these critical residues revealed in the structure of the CT domain active sites of RePC and SaPC 4,12 are fully consistent with previous steady-state ${ }^{6}$ and kinetic isotope effect experiments. ${ }^{7,8}$ The current study allows for an accurate and complete description of the carboxyl transfer mechanism occurring in the CT domain of PC which supported by both biochemical and structural data.

\section{Supplementary Material}

\section{Supplementary Information}

Table S1. Primer Sequences for Carboxyl Transfer

Domain Mutations

\begin{tabular}{ll}
\hline Mutant & Primer sequence \\
\hline T882A & 5'-atcgtcaaggtggcgccatcctcca-3' \\
& 5'-tggaggatggcgccaccttgacgat-3' \\
T882C & 5'-tatcgtcaaggtgtgcccatcctccaagg-3' \\
& 5'-ccttggaggatgggcacaccttgacgata-3' \\
T882S & 5'-cgtcaaggtgtcgccatcctccaaggtcg-3' \\
& 5'-cgaccttggaggatggcgacaccttgacg-3' \\
Q844L & 5'-gaaatgccgggcggcctgttcaccaacctcaagg-3' \\
& 3'-ccttgaggttggtgaacaggccghcccggcattc-3' \\
S885A & 5'-gtgacgccatccgccaaggtcotcg-3' \\
& 5'-cgacgaccttggcggatggcgtcac-3' \\
\hline
\end{tabular}

\section{Footnotes}

†This work was supported by NIH Grant GM070455 to W.W.C.

${ }^{1}$ Abbreviations: PC, pyruvate carboxylase; BC, biotin carboxylase; CT, carboxyl transferase; BCCP, biotin carboxyl carrier protein; ATP,

Biochemistry, Vol 48, No. 20 (May 26, 2009): pg. 4305-4313. DOI. This article is (c) American Chemical Society and permission has been granted for this version to appear in e-Publications@Marquette. American Chemical Society does not grant permission for this article to be further copied/distributed or hosted elsewhere without the express permission from American Chemical Society. 
NOT THE PUBLISHED VERSION; this is the author's final, peer-reviewed manuscript. The published version may be accessed by following the link in the citation at the bottom of the page.

adenosine triphosphate; ADP, adenosine diphosphate; TCA, Tricarboxylic acid; RePC, Rhizobium etli PC; hPC, human PC; SaPC, Staphylococcus aureus PC; BirA, biotin protein ligase; IPTG, isopropylbeta-D-thiogalactopyranoside.

SUPPORTING INFORMATION. Supporting Information Available. Primer sequences used to generate the carboxyl transferase domain mutations are shown in Table S1. This material is available free of charge via the Internet at http://pubs.acs.org.

\section{References}

${ }^{1}$ Jitrapakdee S, Vidal-Puig A, Wallace JC. Anaplerotic roles of pyruvate carboxylase in mammalian tissues. Cell. Mol. Life Sci. 2006;63:843854.

${ }^{2}$ For recent reviews see (a) Jitrapakdee S, St. Maurice M, Rayment I, Cleland WW, Wallace JC, Attwood PV. Structure, mechanism and regulation of pyruvate carboxylase. Biochem. J. 2008;413:369-387. (b)

Jitrapakdee S, Wallace JC. Structure, function and regulation of pyruvate carboxylase. Biochem. J. 1999;340:1-16. 1999. (c) Wallace JC, Jitrapakdee S, Chapman-Smith A. Pyruvate carboxylase. Int. J. Biochem. Cell Biol. 1998;30:1-5.

${ }^{3}$ (a) Knowles JR. The mechanism of biotin-dependent enzymes. Ann. Rev. Biochem. 1989;58:195-221. (b) Wood HG, Barden RE. Biotin enzymes. Ann. Rev. Biochem. 1977;46:385-413. (c) Lane MD, Young $\mathrm{DL}$, Lynen $\mathrm{F}$. The enzymatic synthesis of the holotranscarboxylase from apotranscarboxylase and (+)-biotin. I. Purification of the apoenzyme and synthetase; characteristics of the reaction. J. Biol. Chem. 1964;239:2858-2864. (d) Lynen F, Knappe J, Lorch E, Juttig G, Ringlimann E. Die biochemische funktiondes biotin. Angew. Chem. $1959 ; 71: 481-486$.

${ }^{4}$ St. Maurice M, Reinhardt L, Surinya KH, Attwood PV, Wallace JC, Cleland WW, Rayment I. Domain architecture of pyruvate carboxylase, a biotin-dependent multifunctional enzyme. Science. 2007;317:10761079.

${ }^{5}$ Attwood PV, Wallace JC. Chemical and catalytic mechanisms of carboxyl transfer reactions in biotin-dependent enzymes. Acc. Chem. Res. 2002;35:113-120.

${ }^{6}$ Attwood PV, Tipton PA, Cleland WW. Carbon-13 and deuterium isotope effects on oxaloacetate decarboxylation by pyruvate carboxylase. Biochemistry. 1986;25:8197-8205.

Biochemistry, Vol 48, No. 20 (May 26, 2009): pg. 4305-4313. DOI. This article is (C) American Chemical Society and permission has been granted for this version to appear in e-Publications@Marquette. American Chemical Society does not grant permission for this article to be further copied/distributed or hosted elsewhere without the express permission from American Chemical Society. 
NOT THE PUBLISHED VERSION; this is the author's final, peer-reviewed manuscript. The published version may be accessed by following the link in the citation at the bottom of the page.

${ }^{7}$ Branson JP, Nezic M, Jitrapadkee S, Wallace JC, Attwood PV. Kinetic characterization of yeast pyruvate carboxylase isoenzyme Pyc1 and the Pyc1 mutants, C249A. Biochemistry. 2004;43:1075-1081.

${ }^{8}$ Attwood PV, Cleland WW. Decarboxylation of oxaloacetate by pyruvate carboxylase. Biochemistry. 1986;25:8191-8196.

${ }^{9}$ Cheung $Y-F$, Walsh $C$. Studies on the intramolecular and intermolecular kinetic isotope effects in pyruvate carboxylase catalysis. Biochemistry. $1976 ; 15: 3749-3754$.

${ }^{10}$ Hall PR, Zheng R, Antony L, Pusztai-Carey M, Carey PR, Yee VC. Transcarboxylase $5 S$ structures: assembly and catalytic mechanism of a multienzyme complex subunit. EMBO J. 2004;23:3621-3631.

${ }^{11}$ Young-Biao J, Islam MN, Sueda S, Kondo H. Identification of the catalytic residues involved in the carboxyl transfer of pyruvate carboxylase. Biochemistry. 2004;43:5912-5920.

${ }^{12}$ Xiang S, Tong L. Crystal structures of human and Staphylococcus aureus pyruvate carboxylase and molecular insights into the carboxyl transfer mechanism. Nature Struct. Mol. Biol. 2008;15:295-302.

${ }^{13}$ Dunn MF, Encarnación S, Araíza G, Vargas MC, Dávalos A, Peralta H, Mora $Y$, Mora J. Pyruvate carboxylase from Rhizobium etli: mutant characterization, nucleotide sequence, and physiological role. J. Bacteriol. 1996;178:5960-5970.

${ }^{14}$ Jitrapadkee S, Surinya KH, Adina-Zada A, Polyak SW, Stojkoski C, Smyth R, Booker GW, Cleland WW, Attwood PV, Wallace JC. Conserved Glu40 and Glu433 of the biotin carboxylase domain of yeast pyruvate carboxylase I isoenzyme are essential for the association of tetramers. Int. J. Biochem. Cell Biol. 2007;39:2130-2134.

${ }^{15}$ Chapman-Smith A, Turner DL, Cronan JE, Jr, Morris TW, Wallace JC. Expression, biotinylation and purification of a biotin-domain peptide from the biotin carboxy carrier protein of Escherichia coli acetyl-CoA carboxylase. Biochem. ]. 1994;302:881-887. [

${ }^{16}$ Attwood PV, Graneri BDLA. Pyruvate carboxylase catalysis of phosphate transfer between carbamoyl phosphate and ADP. Biochem. J. $1991 ; 273: 443-448$.

${ }^{17}$ Cleland WW. Statistical analysis of enzyme kinetic data. Methods in Enzymology. 1979;63:103-138.

${ }^{18}$ Adina-Zada A, Jitrapakdee S, Surinya KH, Mcldowie MJ, Piggott MJ, Cleland WW, Wallace JC, Attwood PV. Insight into the mechanism and regulation of pyruvate carboxylase by characterization of a biotindeficient mutant of the Bacillus thermodenitrificans enzyme. Int. J. Biochem. Cell Biol. 2008;40:1743-1752.

${ }^{19}$ McClure WR, Lardy HA, Cleland WW. Rat liver pyruvate carboxylase. I. Preparation, properties and cation specificity. J. Biol. Chem. $1971 ; 246: 3569-3578$.

Biochemistry, Vol 48, No. 20 (May 26, 2009): pg. 4305-4313. DOI. This article is (c) American Chemical Society and permission has been granted for this version to appear in e-Publications@Marquette. American Chemical Society does not grant permission for this article to be further copied/distributed or hosted elsewhere without the express permission from American Chemical Society. 
NOT THE PUBLISHED VERSION; this is the author's final, peer-reviewed manuscript. The published version may be accessed by following the link in the citation at the bottom of the page.

${ }^{20}$ Polakis SF, Guchait RB, Lane MD. On the possible involvement of carbamoyl phosphate intermediate in the adenosine triphosphate-dependent carboxylation of biotin. J. Biol. Chem. 1972;247:1335-1337.

${ }^{21}$ Polakis SF, Guchait RB, Zwergel EE, Lane MD, Cooper TG. Acetyl coenzyme A carboxylase system of Escheria coli. Studies on the mechanisms of the biotin carboxylase- and carboxyltransferase-catalyzed reactions. J. Biol. Chem. 1974;249:6657-6667.

${ }^{22}$ Attwood PV, Graneri BDLA. Bicarbonate-dependent ATP-cleavage catalyzed by pyruvate carboxylase in the absence of pyruvate. Biochem. $\mathrm{J}$. 1992;287:1011-1017.

${ }^{23}$ Molchalkin I, Miller RJ, Evodokimov A, Lightle S, Chan S, Stover CK, Waldrop GL. Structural evidence for substrate-induced synergism and half-sites reactivity in biotin carboxylase. Prot. Science. 2008;17:1706-1718.

${ }^{24}$ Goodall GJ, Baldwin GS, Wallace JC, Keech DB. Factors that influence the translocation of the $N$-carboxybiotin moiety between the two sub-sites of pyruvate carboxylase. Biochem. J. 1981;199:603-609.

${ }^{25}$ (a) Rudnick G, Abeles RH. Reaction mechanism and structure of the active site of proline racemase. Biochemistry. 1975;14:4515-4522. (b)

Buschiazzo A, Giytia M, Schaeffer F, Degrave W, Shepard W, Gregoire C, Chamond N, Cosson A, Berneman A, Coatnoan N, Alzari PM, Minoprio P. Crystal structure, catalytic properties, and mitogenic properties of Trypanosoma cruzi proline racemase. Proc. Nat. Acad. Sci. 2006;103:1705-1710.

${ }^{26}$ Zhao B, Guengerich FP, Voehler M, Waterman MR. Role of active site water molecules and substrate hydroxyl groups in oxygen activation by cytochrome P450 158A2. J. Biol. Chem. 2005;280:42188-42197.

${ }^{27}$ Susan-Resigna $D$, Nowak $T$. The proton transfer step catalyzed by yeast pyruvate kinase. J. Biol. Chem. 2003;278(15):12660-12671.

Biochemistry, Vol 48, No. 20 (May 26, 2009): pg. 4305-4313. DOI. This article is (c) American Chemical Society and permission has been granted for this version to appear in e-Publications@Marquette. American Chemical Society does not grant permission for this article to be further copied/distributed or hosted elsewhere without the express permission from American Chemical Society. 